\title{
Beyond 'ability': some European alternatives
}

\section{Terry Wrigley}

Forum 2013 special issue:

'Fixed Ability' thinking and ability-based practices in English schools Final draft

The idea that people are fundamentally different in ability has long been a convenient myth for conservatives. Indeed Plato openly admitted that his fable of gold, silver and bronze people was a lie, a story told for the purpose of political manipulation.

Citizens, we shall say to them in our tale, you are brothers, yet God has framed you differently. Some of you have the power of command, and in the composition of these he has mingled gold wherefore also they have the greatest honour; others he has made of silver, to be auxiliaries; others again who are to be husbandmen and craftsmen he has composed of brass and iron; and the species will generally be preserved in the children... Such is the tale; is there any possibility of making our citizens believe in it? (Plato, trans. Jowett, III)

The concept of ability is a node of conflict between the Enlightenment notion of education as human development (Bildung) and the social divisions engendered by a capitalist economy. Education implies human beings becoming more and better than they were; it is quite at odds with the $19^{\text {th }}$ Century notion that schools should simply fit children to the same social position as their parents. Even in Victorian times, we should note, the social arguments were propped up by notions of innate in/ability deriving from the racist pseudo-science of craniometry (see Gould 1996:114seq).

Eventually, after the rise of the British labour movement, it was no longer possible to state openly that working-class children must not be educated 'beyond their station in life'. (The turning point in national policy was around 1906, see Cowburn 1986:122.) Consequently, a spuriously objective device had to be introduced to do that covertly. Binet's tests, a crude but pragmatic tool for identifying which children should be given extra help, were turned into a selection mechanism for stratified school types. (They were also used, in the USA, for immigration control.) The reconstructed IQ test allowed only exceptional children of manual worker origin into grammar schools, and even then only if their families could afford the school uniform and other expenses. It is worth noting that Binet himself deplored this move. He worried that IQ would become a self-fulfilling prophecy, and that rigid labels could become 'an excellent opportunity for getting rid of all the children who trouble us' (Binet 1905:169, cited Gould 1996:181). 
Intelligence testing in England was linked from the start with eugenics (Chitty 2009) and class prejudice (Rose et al. 1984). Burt's academic and practical work was built from the very beginning on class-based axioms of inherited in/ability. While still a student at Oxford, he had written in his undergraduate notebook:

The problem of the very poor - chronic poverty: little prospect of the solution of the problem without the forcible detention of the wreckage of society or otherwise preventing them from propagating their own species. (Rose et al. 1984:87)

When, in his first research project, the sons of Oxford academics predictably scored higher than the sons of manual workers, he regarded it as axiomatic that the difference must be genetic (Burt 1909:179, cited Gould 1996:305). He clung to the mechanistic notion of 'capacity', derived from the 19th Century skull-measurers:

Capacity must obviously limit content. It is impossible for a pint jug to hold more than a pint of milk and it is equally impossible for a child's educational attainment to rise higher than his educable capacity. (Burt 1937:477)

The notion that lower class people were born with a fixed IQ has obvious social utility to preserve the 'entitlement' of privilege. Its key US proponents were firmly convinced that people were poor as a result of stupidity:

The people who are doing the drudgery are, as a rule, in their proper places. (Goddard 1919:246)

Speaking to Princeton undergraduates in 1919, Goddard justified gaps of wealth and income in terms of different levels of intelligence:

Now the fact is, that workmen may have a ten year intelligence while you have a twenty. To demand for him such a home as you enjoy is as absurd as it would be to insist that every laborer should receive a graduate fellowship. How can there be such a thing as social equality with this wide range of mental capacity? (cited by Gould 1996:191)

Similarly, in Britain, the political utility of "IQ" in helping the ruling class to preserve the social hierarchy which sustained the practices of IQ testing for educational selection even though the logic of this practice was intellectually preposterous: for over twenty years after 1945 most British ten-year-olds spent an hour each day on test practice to improve their 'innate' intelligence!

The notion of inherited intelligence has lost its scientific credibility for many reasons, including recent advances in genetic understanding: 
The ultra-Darwinists' metaphysical concept of genes as hard, impenetrable and isolated units cannot be correct. Any individual gene can be expressed only against the background of the whole of the rest of the genome. Genes produce gene products which in turn influence other genes, switching them on and off, modulating their activity and function. (Rose, 1998: 215)

And that is before we even consider the effects of environment. The scientific specialism of epigenetics has established that gene expression can change without changes in the underlying DNA sequence, and that environmental factors such as nutrition or pollutants can, in effect, switch genes on and off.

(See also Wrigley 2003, ch 5)

\section{Divide and dumb down}

Despite the collapse of its scientific foundations, so many common practices of school organisation depend upon the notion of 'ability'. This is hegemonic in the sense that unquestioned practices which create and sustain a 'common sense' ideology.

Student teachers blithely speak of children as the 'more able' and the 'not so able', often deploying less euphemistic terminology. Children are systematically divided into 'ability groups' after two or three weeks in primary school, without anybody stopping to ask what this means.

It would, indeed, be an interesting piece of research to discover what Year 1 teachers mean by 'ability', and where they think it comes from: is it inherited, a matter of brain structure, a personality trait, a question of personal interests, the result of 'good' or 'bad' parenting, a consequence of different early experiences, a familiarity with literacy and numeracy, or simply a tautological way of saying 'successful in school'? How many teachers have any doubts that their judgements might be less than objective, let alone entail some cultural bias? Does a tidy, biddable and hard-working pupil stand a better chance of being seen as 'higher ability'? Is ability fixed, or do children tend to stay in their original 'ability groups' because such labelling is a self-fulfilling prophecy?

We particularly need to investigate what is the impact on progress and engagement of the different curricular experience in the various groups. This leads to the children on the Tortoise Table (they can see through the euphemisms), who have generally had less encounters with interesting books at home, having less chance of encountering them at school. Their learning is based less on content of human and natural interest and more on technical skills practised in decontextual ways. Indeed, it is often, quite literally, meaningless. This manifestation of differentiation will only increase if England's education minister 
Michael Gove succeeds in reducing primary school English to spelling, punctuation and grammar - the 'SPAGetti curriculum' (see www.changingschools.org.uk: Curriculum).

There is, as I suggested earlier, a link between the common forms of differentiation and adult roles in a class-divided society. As Michael Rosen recently put it:

Capitalists want different things, different kinds of workforce. The prime requirement for cleaners and so on is that they obey orders, that they do not receive too much education of any kind. For the others, they need people to work on their own, to have ideas. This is what they call in education 'differentiation'. What capitalism requires lies behind all the streaming. But it is produced by capitalism's demands, not by the learners. Z level streaming produces the failures that the system wants. (Rosen 2012)

Recognizing this relationship is not, however, fatalistic determinism. Other social factors, including different national traditions and professional cultures, can moderate this tendency. It operates quite rigidly in education systems such as England, whereas across Scandinavia mixed-ability teaching is the norm. Even in Germany, a country which is plagued by a segregated and hierarchical secondary school system, with serious consequences for overall school achievement (Baumert and Schümer 2002), there are some outstanding models of alternative practice.

The following sections of this article draw upon particular models of differentiation developed in Denmark and Germany. A government-funded differentiation initiative in Denmark in the 1990s (Krogh-Jespersen et al 1998) is summarised here and then related to another example, the official guidelines on teaching social subjects (samfundsfag) to 13-16 year olds. The article continues with recently published books written by teachers at two remarkable Bielefeld schools (von der Groeben 2008; Boller and Lau eds 2010). The Laborschule (laboratory school) and the Oberstufenkolleg (sixth form college) were established nearly 40 years ago to design and evaluate new approaches to school organisation and curriculum; they act as a stimulus for educational development across Germany and internationally.

These international examples are particularly illuminating given the hierarchical and segregationist nature of differentiation in the UK, and the inherent dangers of stigmatising children as 'less able'. Such alternative practices cannot simply be copied or transplanted, but they can help to extend understanding of how learning can be organised in mixed classrooms.

\section{Involving learners in setting goals}


At the centre of the Danish initiative is the principle that pupils should be involved in determining their own activity. Such involvement in planning connects to an ongoing process of formative assessment. It is summed up in the following quotation:

Aims and evaluation hold a work process together, both for yourself and for your pupils. Just as you must formulate an aim for your teaching, so should each pupil formulate an aim which can be a leading thread in the pupil's work. (Krogh-Jespersen 1988:17)

The authors acknowledge that, at first, the children's aims are likely to derive from the teacher's judgement and teaching, but the learners' capacities to articulate their own targets and direction will grow in dialogue with the teacher.

It is very clear that this is not a matter of 'I am level 4, I want to be a 5'. Pupils first become accustomed to setting aims for themselves in terms of content: when the class is studying wildlife in the woods, some decide to concentrate on owls and others on squirrels. They also make decisions about how to study, and how to present and share their knowledge.

A Year 2 pupil wrote and drew a book about owls. She was so enthusiastic about her book that she wanted to visit the nursery class and read them her book. When she suggested this, she recognised that some parts of her book would need further explanation for the younger children. She was nervous, but had a great response from the nursery children. (p19)

The teacher generally starts off the broad theme but the initiative can also come from pupils. After the initial 'inspiration stage', the class are engaged in an open-ended discussion out of which various issues and problems emerge. Individuals and groups then formulate not only the specific content focus of their own investigation, but also the problems and dilemmas they are curious about, which determines the form their investigation will take.

There is some resemblance between this structure and 'projects' or 'themes' as they were understood in more progressive times in British schools. However, a key issue in the Danish model is the notion of problematisation, on a collective and individual level, and in dialogue with the teacher. Without this, project work easily turns into a collection curriculum. (Older readers will remember occasions when each pupil gathered random information from reference books for their individual 'project', ending up with descriptions of 10-15 different Tudor costumes or vintage cars. At its worst, it led to beautiful copying and drawing but little by way of cognitive development.)

The dialogic process of planning and assessment also includes core skills such as literacy: 
I am good at sitting and reading. I can understand what books are about, and I am good at telling other people about the story... I want to learn to spell long words, and to spot the root words they are made from. (year 3) (p27)

Older pupils comment on how they chose to sit on a bench outside the classroom to think over where the plot might go, based on the problems their characters faced.

The openness of the structure is common for all ages in Danish schools. It was particularly fostered by the 1993 Education Law which placed great importance on democratic learning and learning for democracy.

Schools should prepare pupils for joint decision-making, co-responsibility, rights and duties in a society based on freedom and active democratic participation. Teaching and the daily life of schools must therefore be built on principles of intellectual freedom, equality and democracy (Danish Parliament, 1993: ch 1, §1)

A classic structure for projects is exemplified in the guidance for social studies (Samfundsfag) around the ages of 13-16. Here the method described consists of four stages:

i) The teacher seeks to engage the class's interest in a common theme or situation. Alternatively, a current issue is raised by some of the pupils, e.g. based on recent news or a local situation.

ii) Initial discussion (whole class, also groups) identifies interesting aspects and issues. During this stage, the teacher suggests ways of drawing on disciplinary knowledge and techniques to support understanding and investigation.

iii) Small groups (or individuals) undertake specific research.

iv) They present their findings to the whole class. It is suggested that this stage should, where possible, be more than just sharing information, and that pupils should design activities which stimulate further engaged discussion in the class.

(Undervisningsministeriet 1995)

This presents many opportunities for initiative and personal learning, but also for the teacher to develop pupils' ideas or challenge misunderstandings.

Further variations are possible, depending on the topic. Projects can also involve direct involvement in the world. For example, a project might involve adding a fifth stage, with students taking their findings and concerns out into the wider community. Alternatively, the problem which generates the project might be a real problem regarding a local hospital, environmental problems or leisure facilities. 
I have explored this methodology with PGCE students in Edinburgh in the context of an elective course on Education for Citizenship, in relation to the issue of asylum-seekers and refugees. For stage (1), I invented a simulation based on a mythical dystopic future: Scottish independence had gone wrong, and there was a military coup. The tanks rolling down the Royal Mile were not the Edinburgh Tattoo! Grouped into families, the students react to a sequence of news broadcasts. At one point, a member of each family goes into hiding. Eventually, conditions become so bad that the whole family decides to flee, but where to? And what will happen when they reach their destination?

The subsequent discussion (stage 2) revealed wide disparities in how much students knew and in their attitudes. For stage (3), some groups decided to investigate factual questions - reasons for flight, countries of origin, the UK Border Authority's regulations for processing asylum seekers - while others with more prior knowledge chose to tackle more challenging political and ideological issues - national identity, attitudes to migration, xenophobia and racism, moral responsibility, the arms trade. The differentiation which occurred was determined by the students themselves, rather than imposed by the teacher; it did not involve hierarchy, stigma, or artificial limitations on learning. All the students were able to learn from each other and develop their understanding and attitudes during stage (4).

(For a further introduction to project method and other 'open architectures', see www.changingschools.org.uk/T4X/Tx413.pdf)

\section{Being positive about diversity}

Annemarie von der Groeben was deputy at the Bielefeld Laborschule for many years until her recent retirement. Her book (2008) makes it plain that diversity is an educational asset, not a problem: in English its title translates as Using Diversity: Learning Better in Heterogeneous Groups and the book opens with the phrase: Saying yes to differences.

The Laboratory School (Thurn 2012; Wrigley 2006:117seq) is a comprehensive school for 516 year olds, based firmly on principles of mixed ability teaching. Contrary to German norms, the school refuses to give grades or marks to children until this is required in the final year for transition to the next stage of education. The school has close relations with the University around its chosen development projects; the staff leading these projects receive part-time release for several years to work with academics and eventually publish. Developments are well supported but also thoroughly and thoughtfully evaluated. Its philosophy draws on European educational reformers, with principles such as learning by 'head, heart and hand' (Pestalozzi) and promoting democratic engagement even when that involves politically controversial matters. Pupil responsibility is encouraged in many ways, such as looking after the school 'zoo', running the disco and reconstructing the outdoor spaces. 
The message is very clear that you cannot simply establish a curriculum for the 'average' child and then vary it: diversity has to be planned for from the start.

Thesis: All teaching which is meant to serve and productively grab hold of the diversity of learners must be conceived and planned from the start with diverse ways of learning in mind; it cannot start out with normed demands. The more consistently we do that, the better we succeed in helping all pupils to achieve their personal best. Put another way: individualisation of learning with the goal that all pupils will make the best possible progress is not the opposite of measuring up to the achievement challenge, it is the best way to do so. (von der Groeben 2008: 28)

There is a great emphasis on learning by experience, but this doesn't mean simply immersion in reality: simulated and focused experiences are also created to enable pupils to (re)construct key ideas and theories. The key point is that such substitute experiences have to be personally meaningful to young people (p31).

Some of the examples which follow are from a unit on gender roles, a topic which emerged within an elective on Ethics. Like the other secondary phase electives, it is available to pupils from four different school years. Thus the class is not only diverse in terms of the pupils in an individual year, there is up to five years difference in the learners' ages, and several of them have chosen the course for a second year running. This tests modes of differentiation to their limits. Like the earlier Danish examples, the curriculum structure supports individual and small group investigations within the learning community of the whole class.

The very first task is designed to elicit pupils' ideas and attitudes, specifically the way they perceive the 'opposite sex'. Pupils can choose from a menu of alternatives, some of which are more abstract or complex than others:

Task 1 (for everybody)

- The title might be: She (or He). You describe your dream partner.

- You can, so to speak, slip into the 'other skin' of the opposite sex, by imagining spending a day as a boy / girl.

- You could write a short essay on the theme 'If I had suddenly become a boy (girl), would I be a different person?'

- You can choose another way of dealing with this theme (but talk it through with your teacher first.) (p42) 
Those pupils who are willing read their personal texts aloud to the group, while the others receive a confidential response from the teacher. Pupils are invited to give feedback to one another, after careful instruction, for example:

Step one: check your understanding, say what particularly interests you ("I noticed that...”. No judgements at this stage please. (p43)

During this stage, the pupils are also asked to provide ideas for things they would like to study and ways of learning. These are collated by a team of four pupils - those who were in the class the previous year - who meet outside of the lesson to write up a common list. The ideas are well received, but it would take years to complete, so the class suggest a more manageable plan. This consists of some common activities for the whole class, and some choices for small groups to pursue in parallel with one another.

\section{Overview: the Gender Roles unit}

Collectively, with the whole class:

- Reflect about role models: which women and men are seen as role models by young people today? Why? (collective reflection)

- Expectations of the other sex: how do pupils imagine a partnership? what is the dream woman or man? (personal texts)

- Improvised drama: The first date

- Gender roles and education: how are gender roles established and promoted (using historical examples)?

Divided up among smaller groups:

- Happiness by order: analysis of contact ads in the internet and magazines (collect and interpret various examples, give a talk and lead a discussion with the whole class)

- Historic images of women: make an exhibition of pictures from various periods (develop a commentary and lead people through the exhibition)

- The emergence of the women's movement (give a talk)

- Controversies about gender: neurobiological and sociological modes of explanation. (pp45-6)

A range of texts and images of different kinds are available to the class, including examples from different periods. The social and political construction of gender is exemplified through three rich texts:

i) a burial speech from 1600 in which the deceased is praised for her ideal feminine characteristics (domesticated, hard working, honourable, lacking in vanity, she doesn't read but always obeys God and her husband); 
ii) a poem from 1915 'How our little women must work hard in the war', which tells little girls how they must support soldiers at the front;

iii) Hitler's speech about education, in which he describes the ideal qualities of his Hitler Youth: cruelty, violence, a lack of empathy - they must know how to command and not be intellectual. (p48)

This leads to a great discussion about power, and how it was possible for millions of people to follow these 'ideals' during two world wars? What was the fascination of such male and female stereotypes? Are we free from that today?

At every point, efforts are made to encourage collaboration, drawing on different perceptions and understandings in order to reach a common understanding. For example, when listening to the teacher or an invited expert, pupils work in pairs, each making their own notes, comparing them, and preparing questions for clarification. Although not everybody in a small group has to read every text, they have to share their understandings.

Alternative suggestions are provided on how they might respond to more challenging texts, to make them accessible to all, using a 'You can...' menu. For example, to analyse the burial speech:

- You can invent a conversation between mother and daughter, in which mother prepares daughter for her future married life: 'You know, my child...'

- You can write a letter to her, explaining how women live today and how our conceptions of a good life have changed.

- You can role-play an argument: the husband tells his wife how to behave, and she opposes it. (p76)

These approaches enable the learners to engage with texts on a personal level, and bridge between abstract and experiential representations.

Assessment and evaluation is integral to the learning, and takes the form of a verbal commentary, more like a letter than a school report. Pupils derive satisfaction not only from their collaboration and engagement with interesting ideas, but because their learning results in products and presentations for an audience - their own class and others in the school. Again, diversity is supported through a wide range of possible outcomes (a formal talk, a book talk, setting up an exhibition, drama, formal debates, and so on.

\section{Differentiation in the sixth form college}

The Oberstufenkolleg (literally 'upper stage college', or sixth form college) is adjacent to the university and works in collaboration with it. Its courses lead to the Abitur (university entrance exam), but it has many students in their early 20 s from non-traditional backgrounds. 
Although it does not require particular school qualifications for entry, potential students need to take a short internal test to ensure that their German, English and Maths will be sufficient.

The book edited by Sebastian Boller and Ramona Lau (2010, Inner Differentiation in the Upper Secondary Stage in English) is a collaboration between teachers at the college and associated university academics. It explores different organisational forms which can enable diverse students to reach the demanding level required for university study in Germany. This involves not only pursuing a broad range of subjects, unlike England's A-level, but also considerable reflection on the different disciplines (experimental science, interpretative / hermeneutic approaches in literature and the humanities). The aim is not only knowledge acquisition but also the application of knowledge to real-life problems.

There is only space here to highlight some of the seven strategies discussed: Staged Support, Group Puzzle, Learning Stations, Weekly Plan, Project, Learning Diaries and Portfolio. Staged Support involves a common challenge to all the students in a class, to be tackled in pairs or groups. If students get stuck, they can open an envelope which gives them a clue on how to proceed. For example, after several weeks learning about genetics, the challenge is given of explaining why the ancient Jewish Torah forbids circumcision if a mother has lost two sons through bleeding. One of the clues is 'How is the human chromosone made up? How are men and women genetically different?' The clues are staged, gradually giving closer guidance, and are meant to suggest ways of proceeding, rather than giving answers. For example:

- paraphrasing - 'Explain the task in your own words'

- focusing - 'Look carefully at this piece of data on the task sheet'

- elaboration of the subsidiary goals - 'Think about which scientific law might be relevant'

- activation of prior knowledge - 'How are men and women genetically different?'

- visualisation - 'Make a sketch which shows how the sun's rays reach the ground'

- verification - 'Write out the stages in your solution one after the other'

Group Puzzle is a well established form of group work, whereby the class is divided into small 'puzzle groups', each of which sends a representative to form an 'expert group'. The knowledge gained in the expert groups contributes, within each puzzle group, to a complex understanding. It encourages students to work to gain sufficient understanding to share clearly with others. For example, a sociology class grapples with the differences between different 
theoretical paradigms. The puzzle groups send representatives to make up expert groups each concerned with a different social theorist such as Marx, Weber or Durkheim.

Learning Stations are also quite widely known, though more frequently used in the UK for younger learners. Each student or group can move on when ready and doesn't have to complete all the stations. Some can be labelled compulsory, others optional. Also, stations can offer different modes of learning, for example Cells and their components has stations for carrying out an experiment, watching a film, or writing an explanation. A unit to improve Spanish grammar has exercises arranged on 12 tables, with individual students moving from one to another once they feel sufficiently confident.

Project Method was introduced in an earlier section. It was originally articulated by John Dewey and William Kilpatrick, as a way of making learning more real: learning which starts in the real world and ends with a real product. It was also conceived as learning for democracy, particularly when the goal connects with some real social intervention. Examples given include creating an exhibition on World War I, with different groups researching and presenting e.g. propaganda, or everyday life on the 'home front'. A politics class working on the theme Turks in Germany, and the role of Turkey in Europe allows students to draw on their particular skills such as music, acting, filming or languages. Groups of students use their initiative to organise visits to a mosque or conduct interviews with students of Turkish ethnicity about their sense of identity.

\section{Summary}

This article has, hopefully, given some insights into a variety of ways in which differentiation can be practised without ranking or dividing students according to 'ability'. I will highlight some of their advantages.

1) These methods have a broader sense of student diversity than prior attainment or abstract intelligence: they are premised on students bringing to the task a variety of interests, creative talents, prior knowledge, research skills and political viewpoints.

2) They are not built around a 'standard' task which has to be simplified or elaborated for 'less' or 'more able' students. Rather, they are designed from the beginning with student diversity in mind, offering different openings and pathways.

3) Rather than increasing division, they encourage all the learners to contribute to a common understanding. Students are encouraged to build on their strengths and overcome their weaknesses, within a shared task. 
4) These methods connect, in various ways, with assessment as formative. The teacher's role is diagnostic and advisory, and because the activity is pre-planned (often as teamwork between teachers) teachers can relax and have time to tune in to students' learning process. I have written in various places about much traditional learning being a kind of 'alienated labour': you do what you are told, for as long as instructed, until eventually the teacher collects in the work, and eventually gives you a mark or grade as a kind of surrogate wage. There is no authentic product or real audience, so that (in Marx's terms) exchange value takes precedence over use value. Many of the approaches describes above return ownership to the learner for the learning aim, process of investigation and / or final product. In circumstances like these, it is realistic to speak of the class becoming a 'learning community'.

A key issue underlying the need for differentiation is how to relate experience with abstract theory, and unfortunately misunderstanding this point can lead to oversimplification of the cognitive challenge for pupils who are deemed 'less able'. As a result, students whose technical skills are still limited are often shunted into a diet of low-level exercises with little cognitive challenge or personal interest. As Jim Cummins has consistently argued concerning learners with English as an Additional Language, this is a cul de sac; rather than such exercises (low challenge, experientially weak) these students need higher challenges combined with strong experiential and visual support (Cummins 2000:67seq). Adey and Shayer's research indicates that Piaget may have overestimated how soon young people acquire the capacity for unsupported abstract reasoning: they conclude that no more than 30 percent of students demonstrate the use of abstract thinking by the age of 16 (cited Adey 2012:210). Many of the above methods work with this reality by providing alternative and complementary pathways towards a complex theoretical understanding.

These forms of differentiation offer advantages for all learners. They provide many openings for more advanced students to flourish. Perhaps most important of all, the curriculum is not simplified for students deemed 'less able' in ways which will limit their future development.

\section{References}

Adey, P (2012) From fixed IQ to multiple intelligences. In P Adey and J Dillon (eds) Bad education: debunking myths in education. Maidenhead: Open University Press

Baumert, J and Schümer, G (2002) Family background, selection and achievement: the German experience. Improving Schools 5(3) [based on the German PISA-Consortium's national report for PISA 2000]

Boller, S and Lau, R eds (2010) Innere Differenzierung in der Sekundarstufe II: ein Praxihandbuch für Lehrer/innen. Weinheim: Beltz

Burt, C (1937) The backward child. London: University of London Press

Chitty, C (2009) Eugenics, race and intelligence in education. London: Continuum 
Cowburn, W (1986) Class, ideology and community education. London: Croom Helm

Cummins, J (2000) Language, power and pedagogy: bilingual children in the crossfire.

Clevedon: Multilingual Matters

Danish Parliament (1993) Lov om folkeskolen.

http://inet.dpb.dpu.dk/ress/skolelove/folkeskole/30.06.1993.html Retrieved 18 Nov 2012

Goddard, H (1919) Psychology of the normal and subnormal. New York: Dodd, Mead and Company

Gould, S (1996) The mismeasure of man. New York: Norton

Krogh-Jespersen, K, Methling, A and Striib, A (1998) Inspiration til

undervisningsdifferentiering (Inspiration for differentiating education). Copenhagen:

Undervisningsministeriet (Folkeskoleafdelingen)

Plato (c500BCE) The Republic, book III. trans. B Jowett (2008). Project Gutenberg, http://www.gutenberg.org/ebooks/1497

Rose, S (1998) Lifelines: biology, freedom, determinism. Harmondsworth: Penguin

Rose, S, Kamin, L and Lewontin, R (1984) Not in our genes: biology, ideology and human nature. Harmondsworth: Penguin

Rosen, M (2012) Dear Mr Gove. Presentation at Marxism 2012 conference, London, 8 July. http://swpradiocast.bandcamp.com/track/dear-mr-gove-marxism-2012 (accessed 19.11.2012)

Thurn, S (2012) Development processes in a laboratory school. In T Wrigley, P Thomson and B Lingard (eds) Changing schools: alternative ways to make a world of difference. London: Routledge

Undervisningsministeriet. Folkeskoleafdelingen (1995) Samfundsfag (Faghæfte 5).

Copenhagen: Undervisningsministeriet

von der Groeben, A (2008) Verschiedenheit nutzen: besser lernen in heterogenen Gruppen

[Making use of diversity: learning better in mixed groups]. Berlin: Cornelsen

Wrigley, T (2003) Schools of hope: a new agenda for school improvement. Stoke: Trentham

Books [ch 5: Raising expectations - rethinking 'intelligence', open access

www.changingschools.org.uk/SoHfolder/ch5.pdf (accessed 19.11.2012)

Wrigley, T (2006) Another school is possible. London: Bookmarks 